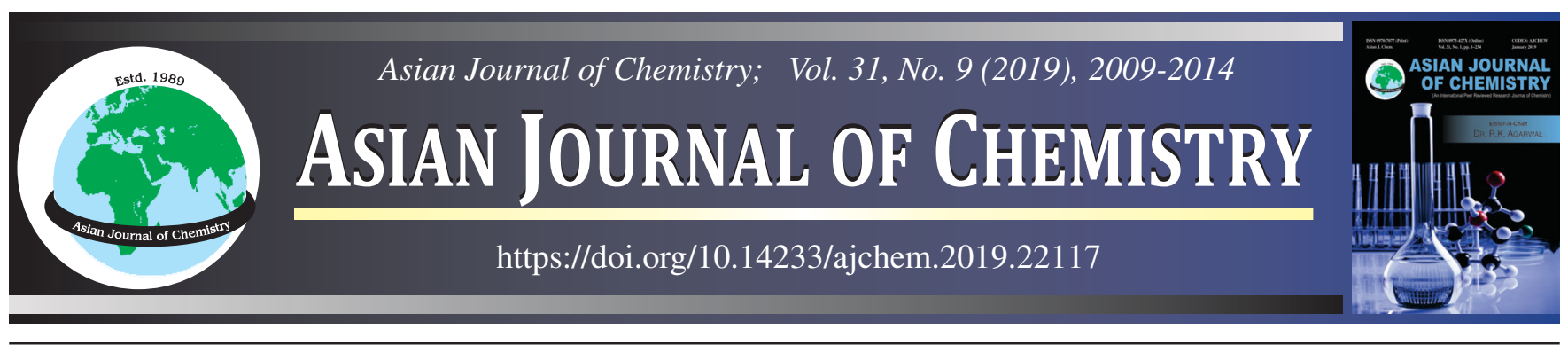

\title{
Mechanical Properties of Stoichiometrically Developed Al-Cu-Mg Cast Alloy Under Controlled Environment
}

\author{
RAKESH KUMAR ${ }^{*}$,• and VARINDER SAHNI
}

Department of Mechanical Engineering, Sant Longowal Institute of Engineering and Technology, Longowal-148106, India

*Corresponding author: Fax: +91 1672 280057; E-mail: rakeshsliet@yahoo.co.in

Present study was carried out to investigate the mechanical properties of newly developed cast aluminum alloy with addition of copper 1.0 $\%$ (at.) and magnesium $1.0 \%$ (at.) in the mole ratio of 1:1:1 Al-Cu-Mg. The selection of $\mathrm{Cu}-\mathrm{Mg}$ on the basis of stoichiometric calculations, 0.55 (at. \%) of copper and 0.21 (at. \%) of magnesium were mixed in liquid aluminium base material, which was prepared in electric furnace. The melt was held at $750{ }^{\circ} \mathrm{C}$ with alloying additions of copper and magnesium for about 5 min to ensure complete homogenization. Further, this liquidous aluminium metal matrix was stirred at $500 \mathrm{rpm}$ for $5 \mathrm{~min}$ and poured at $700 \pm 10^{\circ} \mathrm{C}$ in permanent mild steel mould | at $200{ }^{\circ} \mathrm{C}$ in order to achieve as-cast alloy. Solution treatment at $500{ }^{\circ} \mathrm{C}$ for $1 \mathrm{~h}$ and thermally aged at temperature $160{ }^{\circ} \mathrm{C}$ for $5 \mathrm{~h}$ was exposed. The effect of solution and thermal aging temperature on metallurgical morphology and the role of intermetallic compounds on mechanical properties of as-cast alloy have been studied. The optical microscopy and scanning electron microscopy equipped with energy dispersive spectroscopy were used to identify the intermetallic phases and formation of different precipitates was studied by using X-ray diffraction. The improvement in ultimate tensile strength and hardness values have been reported.

Keywords: Aluminum alloys, Mechanical properties, Solution heat treatment, Thermal aging, Intermetallic compounds.

\section{INTRODUCTION}

Aluminum alloys are next to steels in use as structural metals. Its density is around $1 / 3$ to the steel which makes its use advantageous particularly for space vehicles, aircrafts as well as many types of surface and water borne vehicles [1]. In automobiles, the components such as engine blocks, head, pistons, wheels, etc. are generally aluminum based cast alloys [2]. The low cost and scenario of continuous demands for weight reduction and improvements in fuel efficiency of automobiles have increased pace of research in developing aluminum based cast alloys [3].

The Al-Cu-Mg alloys offer high hardness and strength. Its components contribute the high degree of damage tolerance [4]. The alloys Al-Cu-Mg provides the basis for the development of many other important Al alloys [5]. The first agehardening of aluminum alloy was performed by A. Wilm in year 1909 who patented duralumin of casting components containing $\mathrm{Cu}$ and $\mathrm{Mg}$ substances [6]. The steps consist of solution treatment, quenching and artificial aging. The agehardening mechanism is responsible for strengthening. The mechanism is based on the formation of intermetallic compounds during decomposition of a metastable supersaturated solid solution by performing solution treatment and quenching $[7,8]$.

The composition of alloying elements and casting conditions influence the state of intermetallic phases and finally the mechanical properties of alloys [9]. The copper and magnesium in combination have been used for improving the aging characteristic of the alloys. Some investigators have taken compositions of alloying elements in weight fraction or volume fraction but in arbitrary manner. They have used design of experiments for material compositions as input parameters and different mechanical properties as responses, and finally optimum values of alloying elements are suggested for the given objective.

In place of taking the fraction of alloying elements in arbitrary manner, a pattern based study on stoichiometric weight fraction is explored and presented in the paper. Investigations

This is an open access journal, and articles are distributed under the terms of the Attribution 4.0 International (CC BY 4.0) License. This license lets others distribute, remix, tweak, and build upon your work, even commercially, as long as they credit the author for the original creation. You must give appropriate credit, provide a link to the license, and indicate if changes were made. 
have been made on $\mathrm{Al}-\mathrm{Cu}-\mathrm{Mg}$ casting and results in terms of metallurgical and mechanical properties are presented.

\section{EXPERIMENTAL}

Methodology: Initially to start with the mole ratio of Al$\mathrm{Cu}-\mathrm{Mg}$ were selected as 1:1:1, which results into the stoichiometric ratio of Al-Cu-Mg as 23.496-55.338-21.165. Such a high percentage of $\mathrm{Cu}$ and $\mathrm{Mg}$ cannot be a suitable condition for formation of the $\mathrm{Al}$ based alloy, hence 1 (at. \%) each of $\mathrm{Cu}$ and $\mathrm{Mg}$ as per stoichiometric ratio were taken for mixing with the base metal [9].

A graphite crucible of $2 \mathrm{~kg}$ capacity was used in electric resistance furnace, and the melting temperature was kept at $750{ }^{\circ} \mathrm{C}$ [10] for $5 \mathrm{~min}$. The $\mathrm{Cu}$ and $\mathrm{Mg}$ as decided above were preheated at $200{ }^{\circ} \mathrm{C}$ for $30 \mathrm{~min}$ and mixed in liquidous aluminium metal and stirred for $5 \mathrm{~min}$. The melts were hold at 730 ${ }^{\circ} \mathrm{C}$ for about $30 \mathrm{~min}$ [11] to ensure complete homogenization and poured after degassing into a permanent mould. It refines the microstructure of metallic material which change the morphology and distribution of intermetallic particulates to enhance the mechanical properties of as-cast aluminium alloy. The mechanical tests which include tensile test, microhardness measurement and Charpy V-notch $(\mathrm{CVN})$ tests were performed to obtain cast alloy. Finally, metallographic and mechanical properties of the as-cast alloy have been analyzed.

Metallographic tests: The cast specimens were polished as per standard metallographic procedure by using emery paper of progressive finer grades 400, 600, 800, 1000, 1200, 1500, 2200,2500 and 3000 grit size with single disk machine. They were polished with alumina powder to obtain a mirror like surface by solvyt polishing cloth and continue water supply. Kroll's etchant [distilled water $(92 \mathrm{~mL})+$ nitric acid $(6 \mathrm{~mL})+$ hydrofluoric acid $(2 \mathrm{~mL})]$ was applied for $15 \mathrm{~s}$ to reveal microstructure. Optical microscopy was used to capture microstructures of as-cast and thermally aged aluminium alloys and their photographs taken with the magnification $\times 200$. Fractography was done to determine type of fracture for tensile and CVN samples using scanning electron microscopy JEOL (JSM-6510LV).

Mechanical properties: Tensile specimen samples were tested on a servo hydraulic based digital controlled tensile testing machine of having capacity $50 \mathrm{kN}$ (make: Tinius Olsen, UK, Model-H50KS) and ultimate tensile strength for as-cast alloy and thermally aged cast base alloys was determined. The tensile specimens were prepared in accordance with ASTM E08/E8M-09 standard. The Charpy V-notch (CVN) test was done to measure the fracture toughness of as-cast and aged as-cast. The sample for Charpy V-notch test was prepared as per ASTM
E23-12c standard .The micro hardness measurements were taken by using Vickers micro hardness tester (make: Shimadzu, Japan, Model: HVM-2T) of maximum capacity $2 \mathrm{~kg}$. The testing was carried out at $300 \mathrm{~g}$ load with a dwell of $20 \mathrm{~s}$.

\section{RESULTS AND DISCUSSION}

Spectro analysis: The chemical compositions were tested as per ASTM E 1251-17a using spark emission spectrometer analysis (Model No: LMF_01, Spectromaxx, Germany). The chemical compositions of as-cast alloy and thermally aged alloy were tested using spectrometer and shown in Table- 1 .

The chemical composition on as-cast with solution temperature $500{ }^{\circ} \mathrm{C}$ for $1 \mathrm{~h}$ with $1 \% \mathrm{Cu}, \mathrm{Mg}$ and aged as-cast alloy, temperature $160^{\circ} \mathrm{C}$ for $5 \mathrm{~h}$ with $1 \% \mathrm{Cu}, \mathrm{Mg}$ spectrometer analysis on addition 1.0 (at. \%) copper and magnesium in the base material, there is significant changes in chemical composition of as-cast alloys were observed.

$\mathrm{X}$-ray diffraction: The X-ray diffraction technique was used to show different intermetallic precipitate formations in as-cast and thermally aged alloy which has been observed in $\mathrm{XRD}$ spectra (Fig. 1). In as-cast base aluminium alloy, $\mathrm{AlCu}$ compound has less strength and $\mathrm{Al}_{2} \mathrm{Cu}$ compound contributes to hardness of as-cast alloy. However, when aging was done to $160^{\circ} \mathrm{C}$, formation of $\mathrm{Mg}_{2} \mathrm{Si}$, sigma phase takes place which increases the tensile strength of material (Table-2). At the elevated temperature coarse precipitate $\mathrm{Al}_{2} \mathrm{CuMg}$ was also formed. The aging treatment dissolves $\mathrm{Al}_{2} \mathrm{Cu}$ compound and forms complex precipitate compounds which enhance the strength of matrix.

The complex compounds occur and formation of coarse precipitates such as $\mathrm{Al}_{2} \mathrm{CuMg}$ and $\mathrm{Mg}_{2} \mathrm{Si}$, which enhances the toughness and strength at high temperatures. Sigma phase precipitation was noticed in as cast and aged aluminium alloyed with copper and magnesium which enhances their strength as compared to cast base material.

Optical microscopy: The microstructure consists primarily of a dendritic morphology with dendritic $\alpha$-Al arms, Si-rich platelets, $\mathrm{Al}-\mathrm{Cu}$ phases and $\mathrm{Fe}$-containing intermetallic compounds. The photographs of microstructure of as-cast aluminium, aged as-cast base aluminium, as-cast aluminium with $1 \% \mathrm{Cu}$, $\mathrm{Mg}$ and aged \& as-cast aluminium with $1 \% \mathrm{Cu}, \mathrm{Mg}$ are shown in Fig. 2. There was negligible precipitate formation along the grain boundaries in as-cast aluminium but after aging, nucleation of precipitates at most of the grain boundaries were noticed which enhances the strength. Alloying with copper and magnesium leads to fine precipitate formation. However, as aging was done, these fine precipitates transform into coarser precipi-

TABLE-1

ALLOYING ELEMENTS COMPOSITION (wt. \%)

\begin{tabular}{|c|c|c|c|c|c|c|c|c|c|c|c|c|c|}
\hline $\begin{array}{l}\text { Stage of as-cast } \\
\text { alloys }\end{array}$ & $\mathrm{Al}$ & $\mathrm{Cu}$ & $\mathrm{Mg}$ & $\mathrm{Si}$ & $\mathrm{Mn}$ & $\mathrm{Ni}$ & $\mathrm{Zn}$ & $\mathrm{Pb}$ & $\mathrm{Cr}$ & $\mathrm{Fe}$ & Sn & $\mathrm{Ti}$ & V \\
\hline $\begin{array}{l}\mathrm{SHT} \text { at } 500^{\circ} \mathrm{C} 1 \mathrm{~h} \text {, } \\
\text { As-cast alloy with } \\
1 \% \mathrm{Cu}, \mathrm{Mg}\end{array}$ & 97.73 & 0.3235 & 0.6129 & 0.484 & 0.0110 & 0.0023 & 0.0065 & 0.0045 & 0.0027 & 0.655 & 0.0045 & 0.1438 & 0.0079 \\
\hline $\begin{array}{l}\mathrm{TAG} \text { at } 160^{\circ} \mathrm{C} 5 \mathrm{~h} \text {, } \\
\text { As-cast alloy with } \\
1 \% \mathrm{Cu}, \mathrm{Mg}\end{array}$ & 97.66 & 0.3302 & 0.6679 & 0.495 & 0.0111 & 0.0023 & 0.0068 & 0.0046 & 0.0028 & 0.690 & 0.0042 & 0.1344 & 0.0075 \\
\hline
\end{tabular}




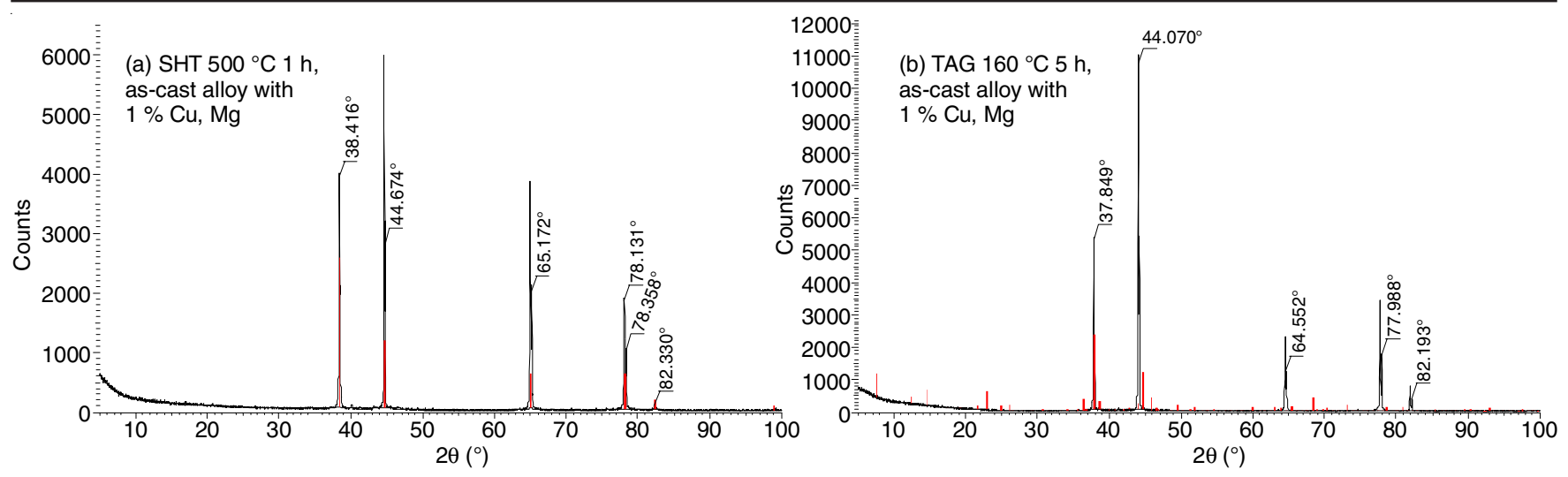

Fig. 1. Intermetallic precipitate formation as per XRD diffraction patterns for (a) SHT $500{ }^{\circ} \mathrm{C} 1 \mathrm{~h}$, as-cast alloy with $1 \% \mathrm{Cu}, \mathrm{Mg}$ (b) TAG 160 ${ }^{\circ} \mathrm{C} 5 \mathrm{~h}$, as-cast alloy with $1 \% \mathrm{Cu}, \mathrm{Mg}$

TABLE-2

\begin{tabular}{ccc|ccc}
\multicolumn{4}{c}{ TABLE-2 } \\
INTERMETALLIC COMPOSITION OF THE OBSERVED PHASE \\
\hline \multicolumn{2}{c}{ Composition corresponding to solution treatment at $500^{\circ} \mathrm{C}$ for $1 \mathrm{~h}$} & \multicolumn{1}{c}{ Composition corresponding to aged temperature at $160{ }^{\circ} \mathrm{C}$ for $5 \mathrm{~h}$} \\
\hline Element & Weight $(\%)$ & Atomic $(\%)$ & Element & Weight $(\%)$ & Atomic $(\%)$ \\
\hline $\mathrm{Mg} \mathrm{K}$ & 0.68 & 0.77 & $\mathrm{Mg} \mathrm{K}$ & 0.73 & 0.82 \\
$\mathrm{Al} \mathrm{K}$ & 97.19 & 98.32 & $\mathrm{Al} \mathrm{K}$ & 96.42 & 2.85 \\
$\mathrm{Cu} \mathrm{K}$ & 2.13 & 0.91 & $\mathrm{Cu} \mathrm{K}$ & 100.00 & 1.23 \\
Totals & 100.00 & & Totals & \\
\hline
\end{tabular}
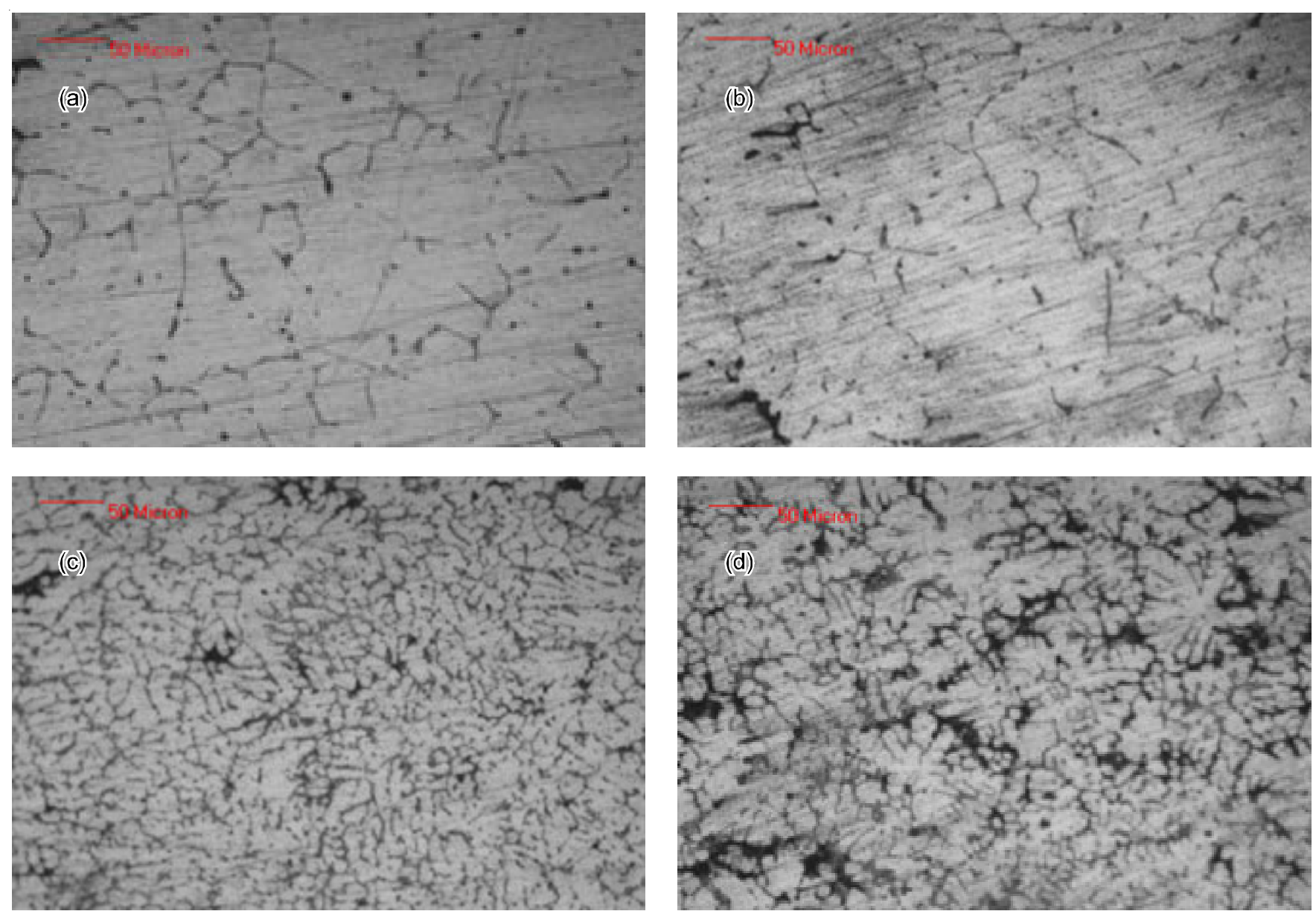

Fig. 2. Photomicrographs at $200 \mathrm{X}$ for (a) SHT $500{ }^{\circ} \mathrm{C} 1 \mathrm{~h}$, as-cast alloy (b) TAG $160{ }^{\circ} \mathrm{C} 5 \mathrm{~h}$, as-cast alloy (c) SHT $500{ }^{\circ} \mathrm{C} 1 \mathrm{~h}$, as-cast alloy with $1 \% \mathrm{Cu}, \mathrm{Mg}$ and (d) $\mathrm{TAG} 160{ }^{\circ} \mathrm{C} 5 \mathrm{~h}$, as-cast alloy with $1 \% \mathrm{Cu}, \mathrm{Mg}$

tates at high temperature and nucleation at grain boundaries were enhanced.
SEM-EDS: The Fe SEM-EDS samples were analyzed for as-cast solution at $500^{\circ} \mathrm{C}, 1 \mathrm{~h}$ and as-cast, aged temperature 
$160^{\circ} \mathrm{C}, 5 \mathrm{~h}$. Magnesium has revealed that peaks for each elements were deducted and compounds formed in the alloy during solidification are "Chinese Script", intermetallic phase, $\mathrm{AlCu}, \mathrm{Al}_{2} \mathrm{CuMg}$, and $\mathrm{Mg}_{2} \mathrm{Si}$ (Fig. 3).

\section{Al}

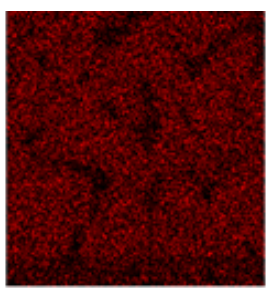

AlK $\alpha 1$

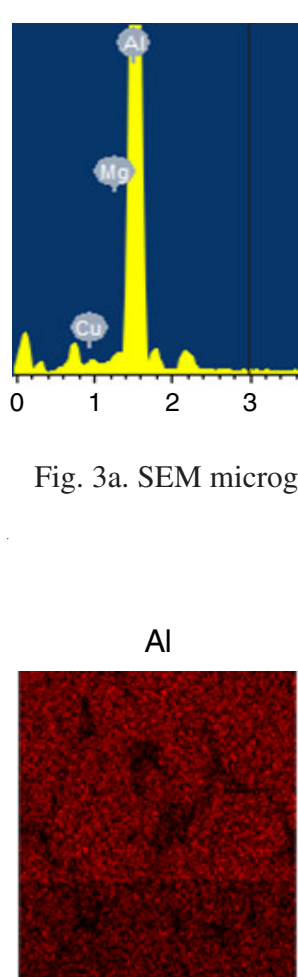

AlK $\alpha 1$
$\mathrm{Cu}$

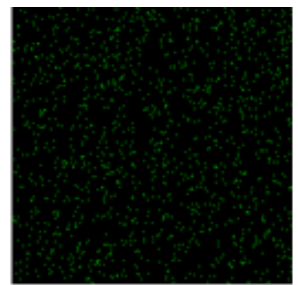

CuK $\alpha 1$
$\mathrm{Mg}$

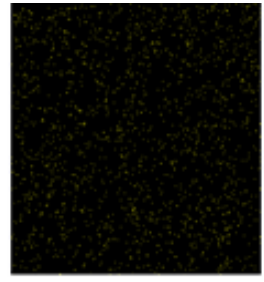

MgKa1_2
Tensile and microhardness studies: Tensile strength and microhardness values of as-cast metal at different stages are shown in Table-3. It can be seen that the hardness of alloy increased obviously at the aged conditions due to nucleation and growth
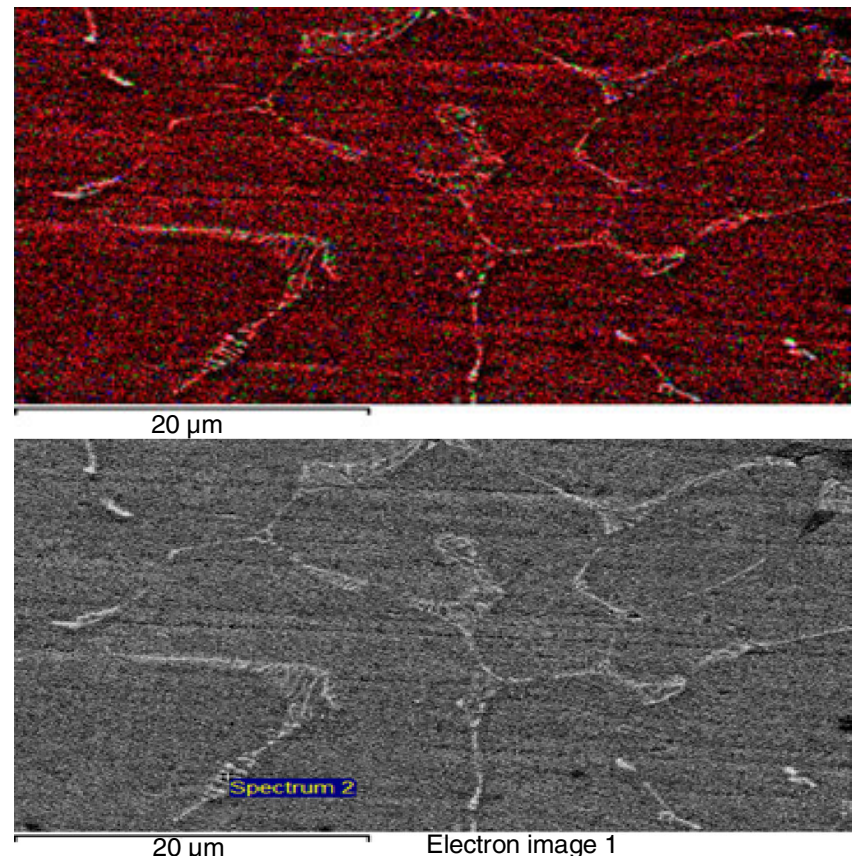

$20 \mu \mathrm{m}$

Electron image 1

ition corresponding to solution treatment at $500{ }^{\circ} \mathrm{C}, 1 \mathrm{~h}$

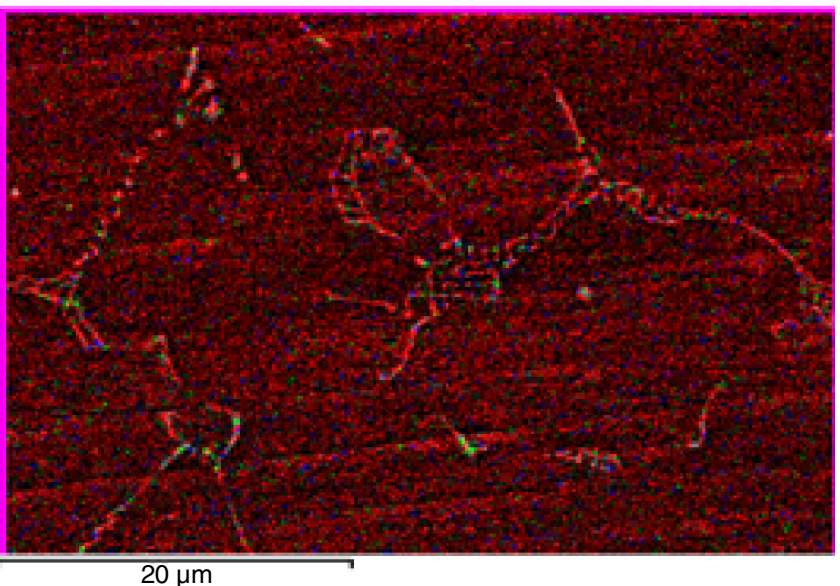

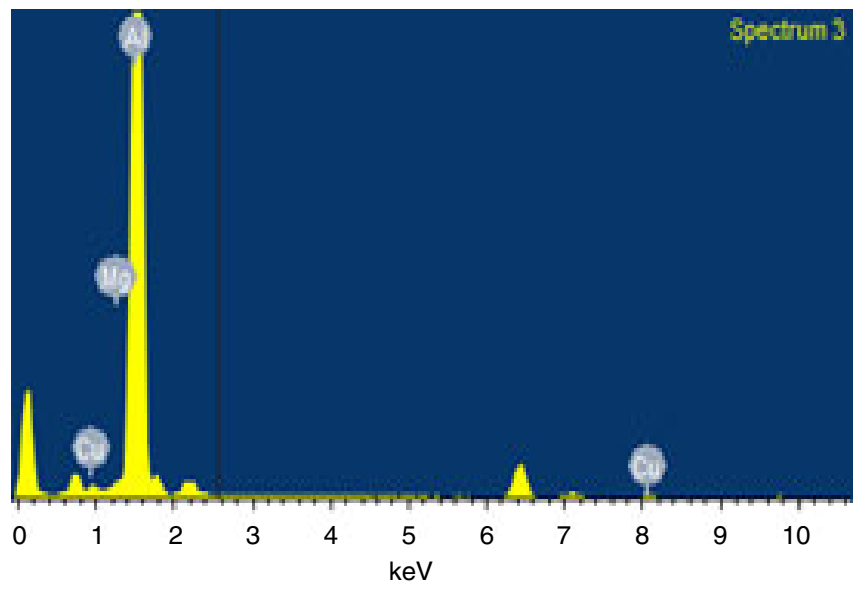

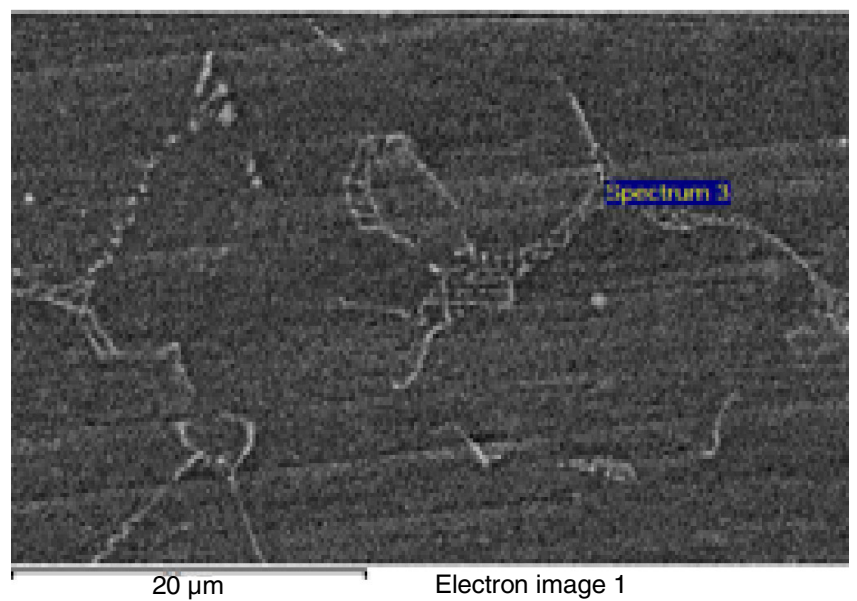

Fig. 3b. SEM micrograph, EDS mapping and measurement of chemical composition corresponding to aged temperature at $160{ }^{\circ} \mathrm{C}$ for $5 \mathrm{~h}$ 


\begin{tabular}{lccc}
\hline \multicolumn{4}{c}{ TABLE-3 } \\
MICROHARDNESS AND ULTIMATE TENSILE STRENGTH VALUES \\
\hline \multicolumn{1}{c}{ as-Cast alloy stage } & $\begin{array}{c}\text { Area of tensile test } \\
\text { specimen }\left(\mathrm{mm}^{2}\right)\end{array}$ & $\begin{array}{c}\text { Ultimate tensile } \\
\text { strength }\left(\mathrm{N} / \mathrm{mm}^{2}\right)\end{array}$ & $\begin{array}{c}\text { Hardness on Brinell (BHN) } \\
\text { at load: } 500 \mathrm{kgf} \text {, time: } 30 \mathrm{~s}\end{array}$ \\
\hline SHT at $500{ }^{\circ} \mathrm{C} 1 \mathrm{~h}$, as-cast alloy & 36 & 132 & 33.50 \\
TAG at $160^{\circ} \mathrm{C} 5 \mathrm{~h}$, as-cast alloy & 36 & 132 & 33.50 \\
SHT at $500{ }^{\circ} \mathrm{C} 1 \mathrm{~h}$, as-cast alloy with $1 \% \mathrm{Cu}, \mathrm{Mg}$ & 36 & 140 & 37.70 \\
TAG at $160{ }^{\circ} \mathrm{C} 5 \mathrm{~h}$, as-cast alloy with $1 \% \mathrm{Cu}, \mathrm{Mg}$ & 36 & 192 & 44.90 \\
\hline SHT $=$ Solution heat treatment; TAG $=$ Thermal aging & & &
\end{tabular}

of the aging precipitates. The dimple morphology was observed in the fractography. In as-cast base metal, small dimples comprising of precipitates were observed but after aging of this ascast base, the small dimples coalesce together to form large dimples which contain hardened precipitates. These hardened participates contribute to increase in ultimate tensile strength of the aged cast. Copper and magnesium act as inoculants when alloyed with aluminium base metal and induce grain refining in matrix by nucleating more nucleation positions for precipitation. Thus, precipitation hardening was induced in alloyed metal matrix while casting which improves the ultimate tensile strength of cast metal. The resulting improvement of mechanical properties after heat treatment is correlated to the intermetallic phase and the precipitation hardening as previously reported.

Impact studies: The results of impact strength in terms of joules of energy to estimate fracture toughness of cast materials are given in Table-4 and their impact fractography is shown in Fig. 4.

In cast base metal, dimple fracture was noticed which corresponds to ductile fracture. When alloyed with copper and magnesium, cast aluminium base metal possess very small

\begin{tabular}{|c|c|}
\hline \multicolumn{2}{|c|}{$\begin{array}{c}\text { TABLE-4 } \\
\text { IMPACT STRENGTH VALUES OF SHT AND } \\
\text { TAG AS-CAST ALLOY CONDITIONS }\end{array}$} \\
\hline As-cast alloy stage & $\begin{array}{l}\text { Impact strength } \\
\text { (joules) }\end{array}$ \\
\hline SHT $500{ }^{\circ} \mathrm{C} 1 \mathrm{~h}$, as-cast alloy & 15 \\
\hline TAG $160^{\circ} \mathrm{C} 5 \mathrm{~h}$, as-cast alloy & 15 \\
\hline SHT $500^{\circ} \mathrm{C} 1 \mathrm{~h}$, as-cast alloy with $1 \% \mathrm{Cu}, \mathrm{Mg}$ & 20 \\
\hline TAG $160^{\circ} \mathrm{C} 5 \mathrm{~h}$, as-cast alloy with $1 \% \mathrm{Cu}, \mathrm{Mg}$ & 9 \\
\hline
\end{tabular}

SHT $=$ Solution heat treatment; TAG $=$ Thermal aging

dimples because of refinement of grain structure of base metal which ultimately improves the fracture toughness of material.

\section{Conclusion}

When copper and magnesium were added in as-cast base aluminium alloy, the elemental change in wt. \% were noticed. These elements enhance intermetallic precipitate formation at the grain boundary of cast base aluminium alloy. So, significant improvement in mechanical properties were observed in copper and magnesium alloyed as-cast alloy and thermally aged conditions. This is because of both intergranular and

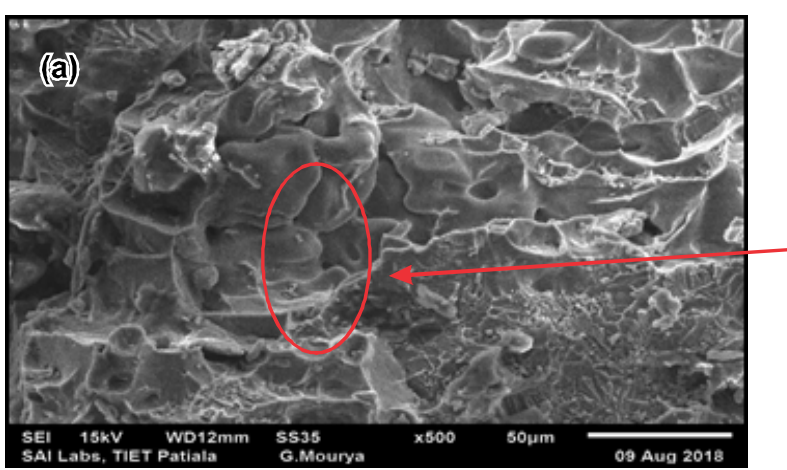

SHT $500{ }^{\circ} \mathrm{C} 1 \mathrm{~h}$, as-cast alloy at $500 \mathrm{X}$

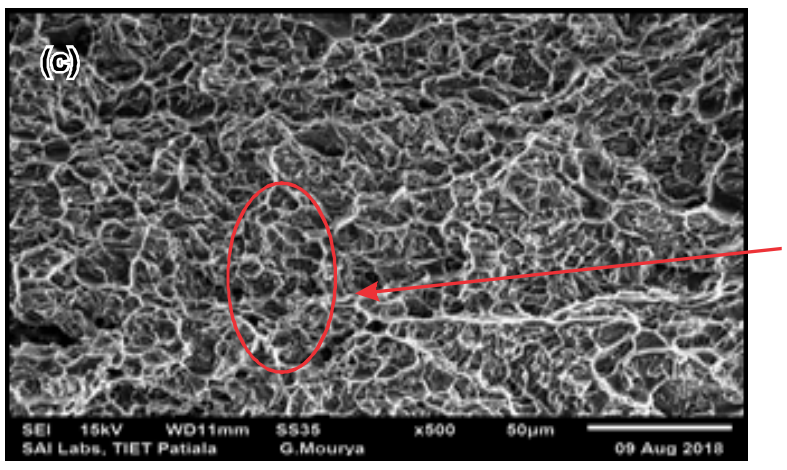

SHT $500^{\circ} \mathrm{C} 1 \mathrm{~h}$, as-cast alloy with $1 \% \mathrm{Cu}, \mathrm{Mg}$ at $500 \mathrm{X}$

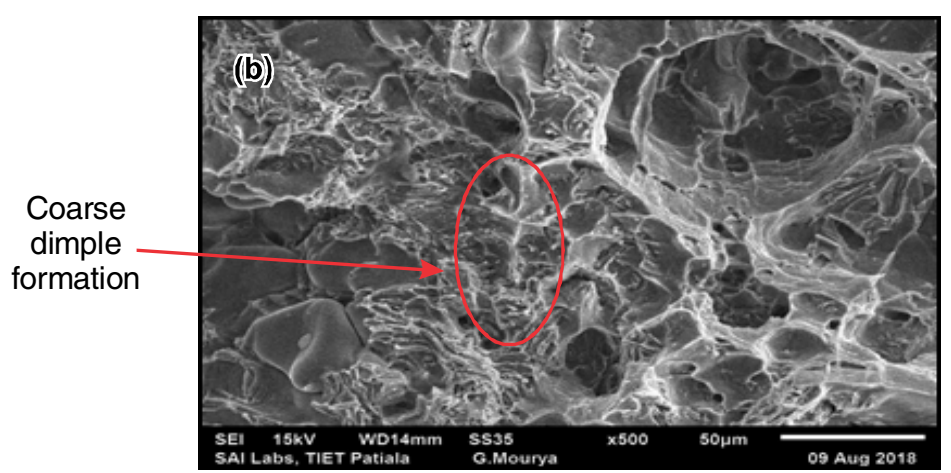

TAG $160^{\circ} \mathrm{C} 5 \mathrm{~h}$, as-cast alloy at $500 \mathrm{X}$

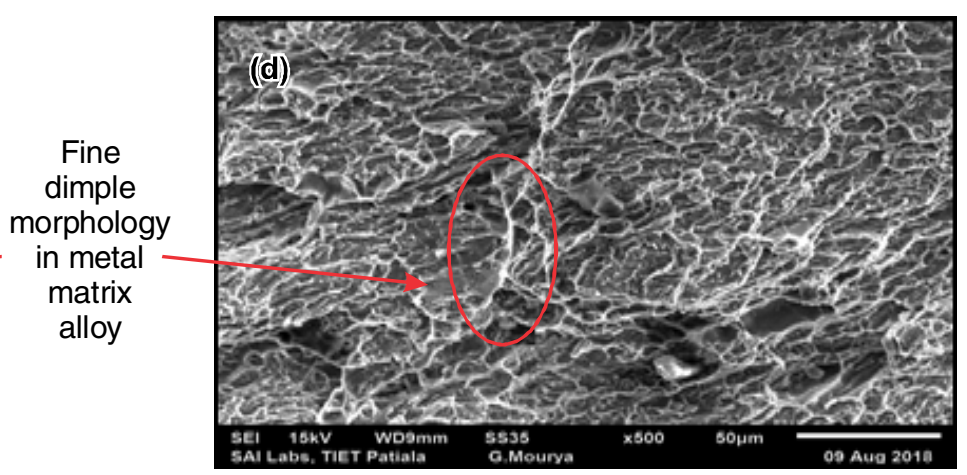

TAG $160{ }^{\circ} \mathrm{C} 5 \mathrm{~h}$, as-cast alloy with $1 \% \mathrm{Cu}, \mathrm{Mg}$ at $500 \mathrm{X}$

Fig. 4. Impact fractography at 500X for (a) as-cast aluminium, (b) TAG $160{ }^{\circ} \mathrm{C} 5 \mathrm{~h}$, as-cast alloy (c) SHT $500{ }^{\circ} \mathrm{C} 1 \mathrm{~h}$, as-cast alloy with $1 \%$ $\mathrm{Cu}, \mathrm{Mg}$ and (d) TAG $160^{\circ} \mathrm{C} 5 \mathrm{~h}$, as-cast alloy with $1 \% \mathrm{Cu}, \mathrm{Mg}$ 
transgranular fine dimples formation and increased nucleation of precipitates in aluminium alloy.

\section{ACKNOWLEDGEMENTS}

This work was carried out in Advance Casting Lab with the financial support from Sant Longowal Institute of Engineering and Technology, Longowal, India under Ministry of Human Resource Development, Government of India.

\section{CONFLICT OF INTEREST}

The authors declare that there is no conflict of interests regarding the publication of this article.

\section{REFERENCES}

1. J.R. Davis, Aluminum and Aluminum Alloys, ASM International (2001).

2. J.R. Brown, The Foseco Foundryman's Handbook, Pergamon Press: Oxford, edn. 11 (1999).

3. S. Cui, R. Mishra and I.-H. Jung, J. Min. Metall. Sect. B-Metall., 54, 119 (2018);

https://doi.org/10.2298/JMMB170512052C.
4. W. Feng, Z. Yanqi, X. Baiqing, Z. Yongan, L. Xiwu, L. Zhihui and L. Hongwei, J. Alloy Compd., 585, 474 (2014); https://doi.org/10.1016/j.jallcom.2013.08.214.

5. S.P. Ringer, K. Hono, I.J. Polmear and T. Sakurai, Appl. Surf. Sci., 94-95, 253 (1996); https://doi.org/10.1016/0169-4332(95)00383-5.

6. C.R. Hutchinson and S.P. Ringer, Metall. Mater. Trans. A, 31, 2721 (2000); https://doi.org/10.1007/BF02830331.

7. M. Zeren, E. Karakulak and S. Gumu, Trans. Nonferr. Metal. Soc. China, 21, 1698 (2011); https://doi.org/10.1016/S1003-6326(11)60917-5.

8. Z. Ma, A.M. Samuel, F.H. Samuel, H.W. Doty and S. Valtierra, Mater. Sci. Eng. A, 490, 36 (2008); https://doi.org/10.1016/j.msea.2008.01.028.

9. R. Kumar and V. Sahni, Indian J. Sci. Technol., 11, 1 (2018); https://doi.org/10.17485/ijst/2018/v11i48/138804.

10. M.F. Ibrahim, E. Samuel, A.M. Samuel, A.M.A. Al-Ahmari and F.H. Samuel, Mater. Design, 32, 2130 (2011); https://doi.org/10.1016/j.matdes.2010.11.040.

11. N.D. Alexopoulos and A. Stylianos, Mater. Sci. Eng. A, 528, 6303 (2011);

https://doi.org/10.1016/j.msea.2011.04.086. 